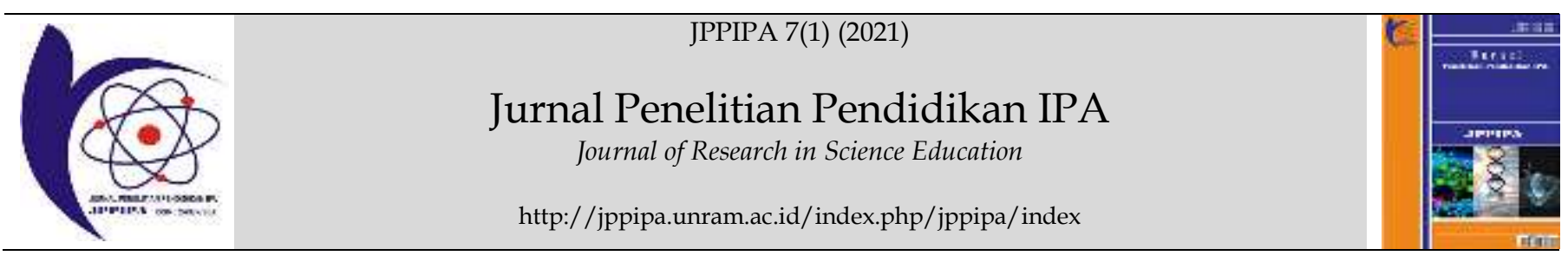

\title{
Ethnoscience-Based Student Worksheet Development to Improve Senior High School Student Creativity
}

\author{
Dika Tri Andani ${ }^{1}$, Abdul Gani2 ${ }^{*}$, Andi Ulfa Tenri Pada ${ }^{3}$, Hafnati Rahmatan ${ }^{3}$ \\ 1Science Education Study Program, Postgraduate Program, Syiah Kuala University, Banda Aceh, Indonesia \\ ${ }^{2}$ Chemical Education Study Program, FKIP Syiah Kuala University, Banda Aceh, Indonesia \\ ${ }^{3}$ Biology Education Study Program, FKIP Syiah Kuala University, Banda Aceh, Indonesia
}

\section{DOI: $10.29303 /$ ippipa.v7i1.457}

\section{Article Info}

Received : July $23^{\text {th }}, 2020$

Revised : September $15^{\text {th }}, 2020$

Accepted: November 16 $16^{\text {th }}, 2020$

\begin{abstract}
Teaching materials that link the material with the surrounding life to foster an entrepreneurial spirit and creative thinking. One proof of its relevance is using plants as natural developers in making pancakes. The purpose of this study was to develop ethnoscience-based worksheets to determine the feasibility and creativity of students. The method used in this research is development research (R\&D) using the ADDIE model. The population for this study was students of class XII IA Senior High School 2 Unggul Ali Hasjmy. The sample was selected purposively, namely 28 students. Data were collected using validation tests and creativity observation sheets. The results showed that the development of worksheets was very feasible to use with the percentage of 85.20 given by the validator. Validation of the creativity observation sheet states that 25 of the 26 items are feasible to use. Student creativity also increased with a percentage of the high category 89.00. Ethnoscience-based worksheets to increase student creativity are feasible to be used as teaching material.
\end{abstract}

Keywords: Development; worksheets; Ethnoscience; Student Creativity

Citation: Andani, D., Gani, A., Pada, A., \& Rahmatan, H. (2020). Ethnoscience-Based Student Worksheet Development to Improve Senior High School Student Creativity. Jurnal Penelitian Pendidikan IPA, 7(1), 26-33. doi:https://doi.org/10.29303/jppipa.v7i1.457

\section{Introduction}

The 2013 curriculum applies interactive, inspirational, fun, and challenging learning. This will spur students to be more motivated in learning and to participate actively. In addition, students can develop creativity and independence according to their talents, interests, and physical development. The 2013 curriculum also forms an entrepreneurial spirit and creative thinking in students to reduce the unemployment rate. The solution to reducing the unemployment rate, namely learning with the concept of entrepreneurship (Sudarmin et al., 2017). This is a good step to prepare for the birth of more entrepreneurs in Indonesia (Darmiyanti, 2017).
One way to help students understand entrepreneurship learning to achieve optimal results is by using student worksheets as a learning resource (Novaliyosi, 2018). Worksheets are one type of learning resource that is systematically compiled by teachers that can be used by students in the learning process independently and can be designed according to their needs in learning activities (Pratama and Siregar., 2019). According to Zahary (2017), designing a good worksheet is not only a form of self-evaluation but also a first step for students to understand the concept of appropriate material according to instructions from a worksheet. The worksheets that are often used in schools in learning craftsmanship and entrepreneurship are not integrated with ethnoscience. The worksheets 
are not attractive to students because it does not have specific goals during the learning process, and causes low learning outcomes for students (Khoiri et al., 2019). These problems can be seen from the results of daily tests of class XII IA students of Senior High School 2 Unggul Ali Hasjmy Aceh Besar for the 2015-2016 school year is 80.55 , the 2016-2017 school year is 81.29 and the 2017-2018 school year is 82.44 . This value is still below the KKM average of 85 for craft and entrepreneurship subjects. This data shows that the results of daily test scores, especially for processing materials, are still categorized as low and incomplete.

Based on the results of observations made by the researcher, it was found that the worksheets with processing material commonly used in learning were the result of the design of the teacher in craft and entrepreneurship subjects at the school. The worksheets applied so far has been less effective, only in the form of practice questions. The worksheets that have been used for presentation are less attractive, there is no economic analysis, and does not invite students to do practicum that produces products by linking local wisdom around them. In addition, based on interviews with the teacher, it was revealed that the learning creativity of students so far was still low, it was seen from 2 to 5 students who only asked, answered, gave opinions, or different ideas in problem-solving.

The solution to this problem is to develop an ethnoscience-based worksheet (Sudarmin et al., 2019). Ethnoscience is a learning approach based on local wisdom in a certain area or region that has cultural values, developing locally from generation to generation (Toharudin, 2017). The concepts that exist in community life are developed in the form of development based on community life activities associated with the concept of science (Fitria and Wisudawati, 2018). Ethnoscience-based worksheets that are integrated into learning will provide new nuances for students (Dewi et al., 2017). Ethnoscience-based worksheets can also increase students' creativity and hard work to learn (Khoiri et al., 2019). The development of ethnoscience-based worksheets was adopted from the research of Rahayu and Sudarmin (2015) who developed an ethnoscience-based integrated science module. Development research being developed is still in the form of modules that need to be innovated into ethnoscience-based worksheets for craftsmanship and entrepreneurship. Researchers need to develop ethnoscience-based worksheets on processing materials because these materials are closely related to life. One proof of its relevance is using plants as natural developers. It is important to develop worksheets so that the learning process runs well, encourages students to be involved in active learning to achieve learning goals, and triggers an increase in student learning outcomes (Dhanti et al., 2019). Research conducted by Septiana et al., (2018) found a relationship between students' learning creativity and learning outcomes.

There are several results of the development and use of ethnoscience-based worksheets that have shown positive effects. Research conducted by Usman et al., (2019) shows that ethnoscience-based learning can improve learning outcomes. In addition, students' activities and responses to ethnoscience-based learning were also high, namely $54.24 \%$ strongly agreed and $39.39 \%$ agreed. Research conducted by Okwara and Upu (2017) shows that ethnoscience-based learning can have a positive impact on student achievement and interest and make students become human beings with character. Other results obtained from Wiyanto et al., (2017) provide results that ethnoscience-based learning is more effective because it uses the environment or equipment around it so it stimulates curiosity.

Based on the explanation of these problems, research on ethnoscience-based worksheets has been carried out. This worksheet can increase student creativity in learning activities developed through ethnoscience so that it can link the material with the surrounding life.

\section{Method}

This study uses the research and development (R\&D) method with the analysis, design, development, implementation, and evaluation (ADDIE) model. The development carried out is an ethnoscience-based worksheet to increase the creativity of students. The ADDIE model is a research design designed to develop products in the form of learning devices.

The population in this study were all students of class XII majoring in IA at Senior High School 2 Unggul Ali Hasjmy Aceh Besar totaling 56, which were spread over two classes, even semester of the 2018/2019 academic year. Sampling was carried out by purposive sampling, namely in the form of target samples based on the low percentage of daily test scores related to processing material in studying craft and entrepreneurship subjects so that the XII-IA 1 class was obtained totaling 28 students.

\section{Result and Discussion}

\section{Ethnoscience Based WORKSHEETS Development}

The ethnoscience-based WORKSHEETS development uses the ADDIE model with the stages, namely analysis, design, development, implementation, and evaluation.

\section{Analysis}


The learning of craftsmanship and entrepreneurship that has been applied so far is still teacher-centered, students only answer the questions found in the worksheets, students are less enthusiastic in answering questions. The solution is to use more varied learning and that involves the active role of students by preparing integrated teaching materials so that students are active and creative in learning activities.

The use of teaching materials in the learning process of craftsmanship and entrepreneurship uses textbooks and worksheets. The worksheets used did not have a link between the material and the culture around students, so they did not know the relationship between the concept of craftsmanship and local life and culture in their environment. Based on the results of the analysis, a solution is sought by developing teaching material in the form of ethnoscience-based worksheets, which can help teachers and students achieve the expected learning objectives, namely optimal creativity. This is supported by research by Siagian et al., (2018) that teachers must be able to design and produce learning tools or teaching materials that are complete and systematic so that they can motivate students to learn actively.

\section{Design}

Ethnoscience-based worksheets are designed using Microsoft Word applications, A4 paper size, times new roman GD letters, and century Gothic letters with 12 letters. These worksheets are also designed with bright colors and images related to the environment and culture around life, with the aim of attracting the attention of students. At this design stage, a learning implementation plan (RPP) is also prepared along with other instruments needed in the research. Ethnoscience-based worksheets provide ethnoscience information regarding some of the local wisdom that exists around the Acehnese people, such as about kue serabi which uses durian leaf extract as a natural developer. Thus the existence of ethnoscience information can provide knowledge to students about the culture contained in the area and instill the values contained in local wisdom in the form of local traditional values (Suastra and Yasmini, 2013). The drawings of some parts of the design of the ethnoscience-based worksheet are presented in Figure 1.
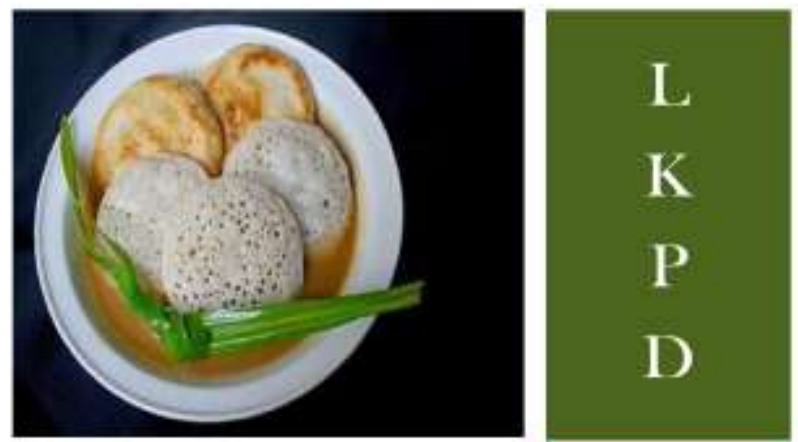

\section{STUDENT WORKSHEETS ETHNOSCIENCE}
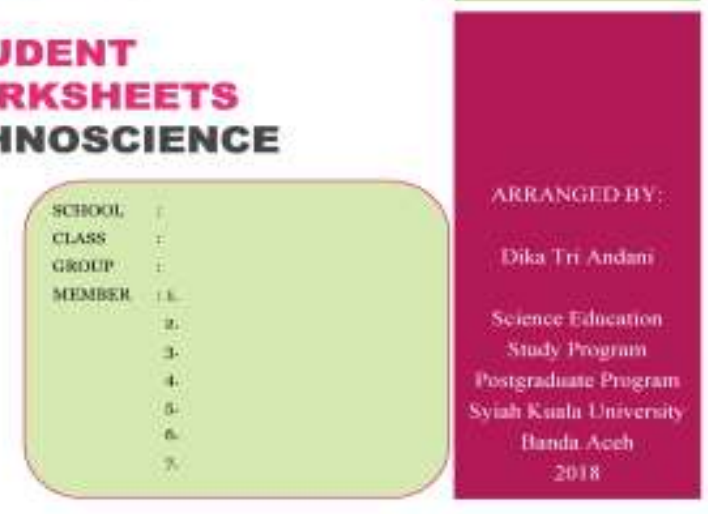

a

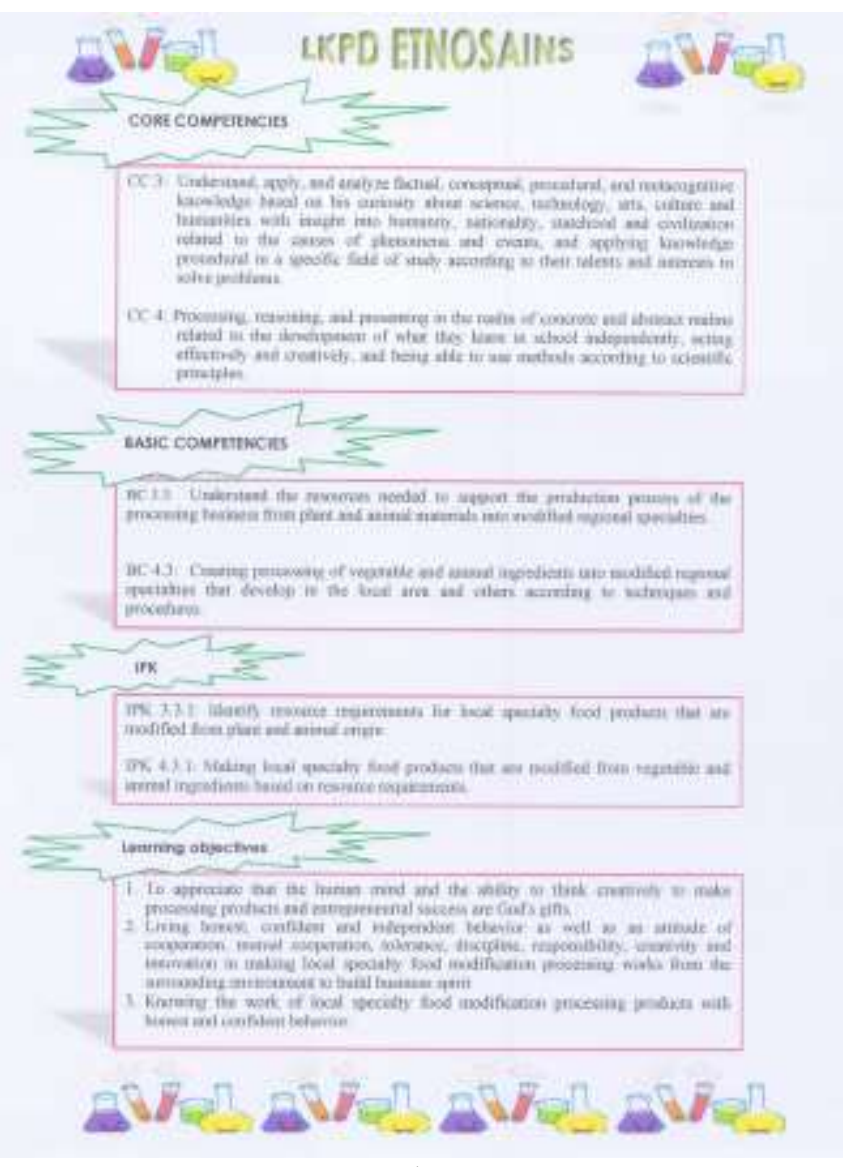

$\mathrm{b}$ 

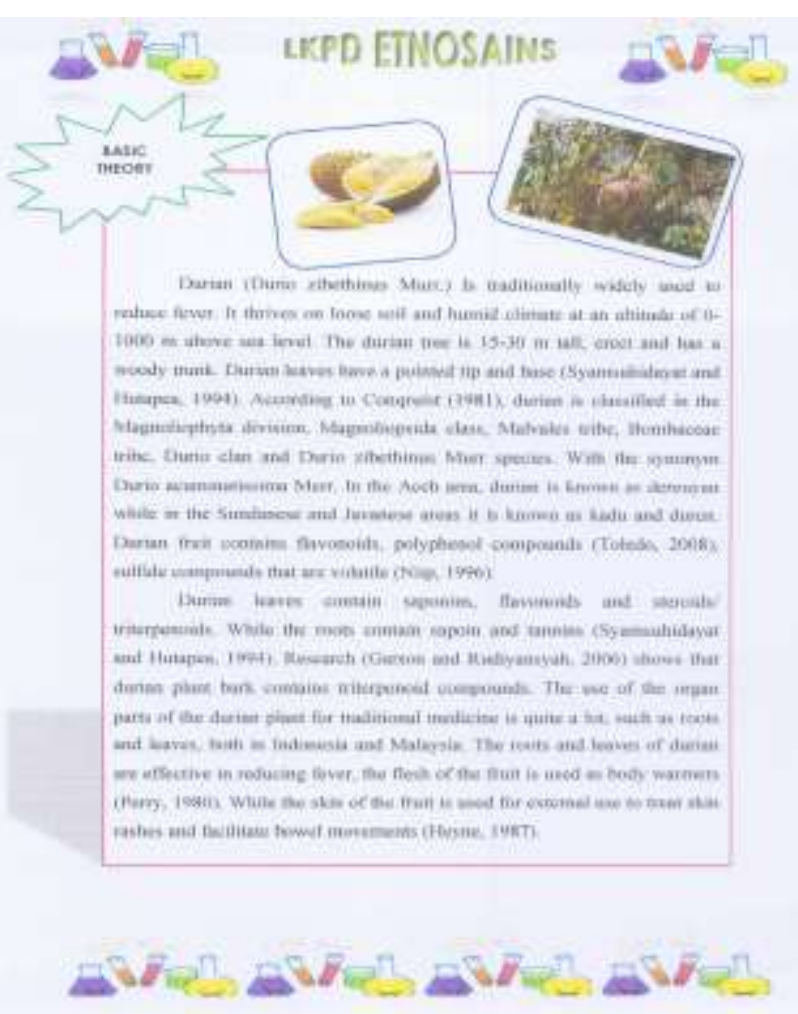

c

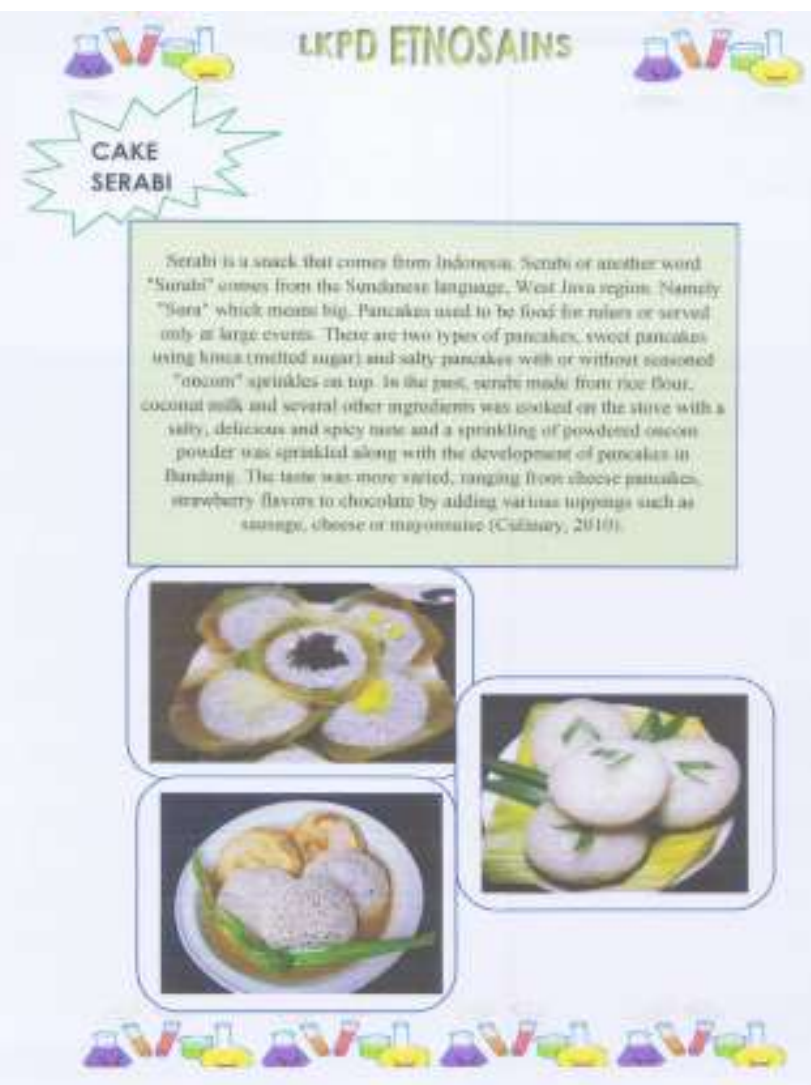

d

Figure 1. Description of the initial design of ethnosciencebased worksheets; (a) cover, (b) KI, KD, GPA, and learning objectives, (c) theoretical basis, (d) understanding.

\section{Development}

The worksheets development is compiled based on the design that has been carried out at the design stage which is adjusted to the RPP. The draft worksheets that have been designed are then given to the supervisor for review and then given to the expert to be assessed in order to obtain input and suggestions. These results will be improved according to the aspects of the assessment based on the content, presentation method, language, completeness, and physical quality of the WORKSHEETS. The following is the assessment by experts of ethnoscience-based worksheets in Table 1. Table 1. Recapitulation of worksheets feasibility assessment by experts

\begin{tabular}{|c|c|c|c|}
\hline No & Aspect & $\begin{array}{c}\text { Worksheets } \\
\text { Assessment } \\
(\%)\end{array}$ & $\begin{array}{l}\text { Validation } \\
\text { Criteria }\end{array}$ \\
\hline 1 & Content Quality & 84.37 & very worthy \\
\hline 2 & $\begin{array}{l}\text { Quality of } \\
\text { Presentation } \\
\text { Method }\end{array}$ & 83.33 & very worthy \\
\hline 3 & Use of Language & 87.50 & very worthy \\
\hline 4 & $\begin{array}{l}\text { Quality of } \\
\text { Completeness }\end{array}$ & 87.50 & very worthy \\
\hline 5 & $\begin{array}{l}\text { Worksheets } \\
\text { Physical Quality }\end{array}$ & 83.33 & very worthy \\
\hline & Average & 85.20 & very worthy \\
\hline
\end{tabular}

Based on Table 1, shows that the average score of the validation results of 2 validators against worksheets is $85.20 \%$ with the very feasible category. In the assessed aspect of the five components, the score range is $83.33 \%-87.50 \%$ with a very decent category, the highest components are components 3 and 4, namely the use of language, the quality of completeness with an average score of $87.50 \%$ very feasible category. . From these data, it can be seen that the language used in this worksheets is considered communicative, besides that it means that the language used is also considered simple, clear and easy to understand by high school grade XII students. In line with the Ministry of National Education (2006) that writing worksheets must pay attention to sentence structure, use of language that is easy to understand as well as a structured text sequence and correct EYD. The lowest components are components 2 and 5, namely the quality of the presentation method, the physical quality of the worksheets with an average score of $83.33 \%$ in the very feasible category. This is because the worksheets are still not systematic so that it can make students confused in filling out the report and relating it to the material being studied at the worksheets. In line with this, according to Khotimah., Et al. (2018) learning oriented to local wisdom is believed to be able to improve problem-solving skills because the learning delivered is in accordance with the conditions in the 
environment so that it can give a contextual impression in learning so that students easily understand the material studied. Overall, the ethnoscience-based worksheets that have been developed are categorized as very feasible to be implemented aimed at increasing student creativity in processing material.

At this development stage, a small-scale trial was also carried out on 1 group (4 students) to see their creativity towards ethnoscience-based worksheets. Based on the results of small-scale trials, it was found that the creativity of students on average was $40.00 \%$ with a low category. The next stage was carried out large-scale trials of 4 groups (28 students), it was obtained that the creativity of students was an average of $86.00 \%$ with a high category.

\section{Implementation}

The process of implementing the worksheets that have been designed, after passing the assessment process and 2 trials. The implementation of these worksheets was carried out at Senior High School 2 Unggul Ali Hasjmy to know the increase in students' creativity towards learning using ethnoscience-based worksheets. The activities of students can be seen in Figure 2.

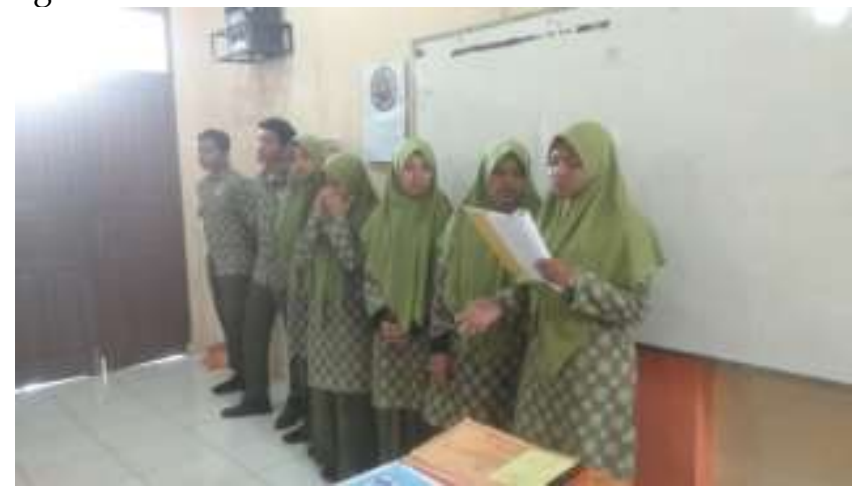

Figure 2. Student activities during learning using ethnoscience-based worksheets.

The durian leaves that have been used by the teacher as natural developer materials cannot be used by students because the teacher wants to know the creativity of students in the process of finding natural developers from other leaves around the environment. The results obtained are durian leaves and soursop leaves that make the pancakes expand naturally. Durian and soursop leaves contain phytochemical compounds. The content of compounds from durian leaves such as saponins, flavonoids, and steroids/triterpenoids (Syamsuhidayat and Hutapea, 1991), while soursop leaves contain alkaloids, tannins, coumarin, flavonoids, and steroids/terpenoids (Asbanu et al., 2019). The activities of students can be seen in Figure 3.

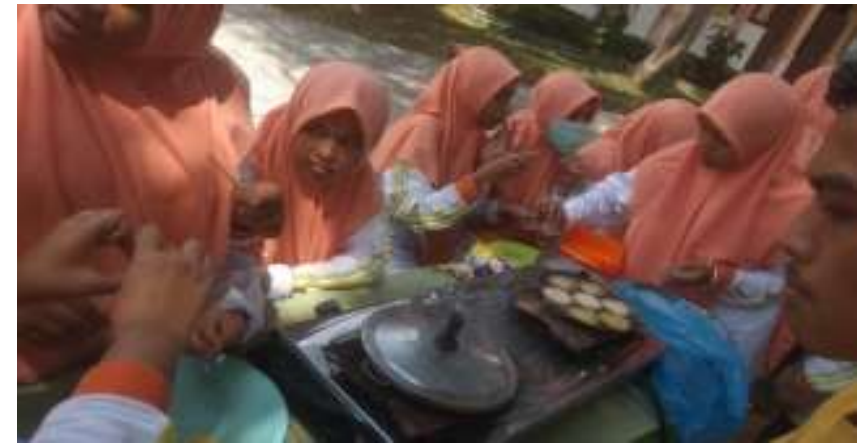

Figure 3. The activities of students during the practicum of making pancakes using natural developers.

\section{Evaluation}

The evaluation stage is called the final stage, at this stage, an evaluation is carried out in the form of an assessment of student creativity using an observation sheet. Student creativity towards ethnoscience-based worksheets is presented in Table 2.

Table 2. Recapitulation of Student Creativity Assessment

\begin{tabular}{llll}
\hline No & Group & Percentage of Creativity & Category \\
\hline 1 & I & 88 & High \\
2 & II & 96 & High \\
3 & III & 88 & High \\
4 & IV & 84 & High \\
Average & 89 & High \\
\hline
\end{tabular}

Based on Table 2, it shows that those who get the highest percentage of creativity are 96, namely group 2 because of the 25 items only 1 item cannot be assessed, namely item number 20 (how to make natural developer extracts is different from other groups). The lowest creativity was $84 \%$, namely group 4 because of the 25 items only 21 items received an assessment on the creativity observation sheet. The average student creativity is 28 people, namely $89 \%$, so it can be said that the creativity of students XII IA 1 Senior High School 2 Unggul Ali Hasjmy is high. This proves that learning using ethnoscience-based worksheets has a good effect so that students are more interested in learning, which results in increased creativity. The ethnoscience approach that was inserted in the worksheets until the development of the ethnosciencebased worksheets on processing materials became a solution to overcome existing problems, as well as providing information to them that the processing material studied was in fact related to the environment and culture around it. This is in accordance with what Nisa et al., (2015) stated that learning with ethnoscience-based teaching materials received a very good response, meaning that students were interested, this was because in the learning process students were not bored because they were interspersed with cultural knowledge around them. 


\section{Creativity Observation Sheet}

This study uses an instrument in the form of student creativity observation sheets that have been validated by 5 expert validators from the counseling guidance department. The following are the results of the validators who have provided an assessment, then the data is processed using the Aiken's $\mathrm{V}$ formula which can be seen in Table 3 .

Table 3. Recapitulation of the assessment of the validation of the creativity observation sheet

\begin{tabular}{|c|c|c|c|c|c|c|c|c|}
\hline \multirow{3}{*}{$\begin{array}{l}\text { No } \\
\text { Item }\end{array}$} & \multicolumn{5}{|c|}{ Validator } & \multirow[t]{3}{*}{$\sum \mathbf{S}$} & \multirow[t]{3}{*}{$\mathbf{V}$} & \multirow[t]{3}{*}{ Category } \\
\hline & $\mathbf{A}$ & $S$ & $\mathbf{A}$ & $\mathbf{R}$ & $\bar{S}$ & & & \\
\hline & $\mathbf{U}$ & D & $S$ & $\mathbf{Y}$ & A & & & \\
\hline 1 & 3 & 3 & 3 & 3 & 3 & 10 & 1 & Very high \\
\hline 2 & 3 & 3 & 3 & 3 & 3 & 10 & 1 & Very high \\
\hline 3 & 3 & 3 & 3 & 3 & 3 & 10 & 1 & Very high \\
\hline 4 & 2 & 2 & 3 & 2 & 3 & 7 & 0,7 & High \\
\hline 5 & 3 & 2 & 3 & 3 & 3 & 9 & 0,9 & Very high \\
\hline 6 & 2 & 2 & 3 & 2 & 3 & 7 & 0,7 & High \\
\hline 7 & 3 & 2 & 3 & 3 & 3 & 9 & 0,9 & Very high \\
\hline 8 & 2 & 2 & 2 & 2 & 2 & 5 & 0,5 & Enough \\
\hline 9 & 3 & 3 & 3 & 3 & 3 & 10 & 1 & Very high \\
\hline 10 & 2 & 3 & 3 & 2 & 3 & 8 & 0,8 & Very high \\
\hline 11 & 3 & 2 & 2 & 3 & 3 & 8 & 0,8 & Very high \\
\hline 12 & 3 & 3 & 3 & 3 & 3 & 10 & 1 & Very high \\
\hline 13 & 3 & 3 & 3 & 3 & 3 & 10 & 1 & Very high \\
\hline 14 & 3 & 3 & 3 & 3 & 3 & 10 & 1 & Very high \\
\hline 15 & 2 & 3 & 3 & 2 & 3 & 8 & 0,8 & Very high \\
\hline 16 & 3 & 3 & 3 & 3 & 3 & 10 & 1 & Very high \\
\hline 17 & 3 & 3 & 3 & 3 & 3 & 10 & 1 & Very high \\
\hline 18 & 3 & 3 & 3 & 3 & 3 & 10 & 1 & Very high \\
\hline 19 & 2 & 3 & 3 & 2 & 3 & 8 & 0,8 & Very high \\
\hline 20 & 3 & 3 & 3 & 3 & 3 & 10 & 1 & Very high \\
\hline 21 & 3 & 3 & 3 & 3 & 3 & 10 & 1 & Very high \\
\hline 22 & 3 & 3 & 3 & 3 & 3 & 10 & 1 & Very high \\
\hline 23 & 3 & 3 & 3 & 3 & 3 & 10 & 1 & Very high \\
\hline 24 & 3 & 3 & 3 & 3 & 3 & 10 & 1 & Very high \\
\hline 25 & 3 & 3 & 3 & 3 & 3 & 10 & 1 & Very high \\
\hline 26 & 3 & 3 & 2 & 3 & 3 & 9 & 0,9 & Very high \\
\hline
\end{tabular}

The data in Table 3 shows that of the 26 statement items there are 23 items with very high criteria, 2 items with high criteria, and 1 item with sufficient criteria. Sufficient criteria are found in item 8 (softcopy evidence/hardcopy of literature appropriate to the project) with a value of $\mathrm{V} 0.5$. This is because these items are not communicative and do not match the contents of the concept to be studied, while the 25 statement items used as creativity observation sheets are in item 1 (students explain fluently the findings of natural developers from the literature), 2 (students are consistent in setting goals for the natural pancake developer project), 3 (students were able to make project objectives related to the literature being read), 4 (each group asked about natural developer), 5 (each group asked about making pancakes), 6 (each group answered about natural developer), 7 (each group answered about making pancakes), 9 (students were able to explain the tools to be used in the project being carried out), 10 (literature that could be different from other groups), 11 (there was a renewal of the literature), 12 (various kinds of findings of natural developers from some literature), 13 (students can suggest different tools used i other groups), 14 (students can suggest the material used is different from other groups), 15 (do not focus on 1 idea used in completing the project), 16 (students are able to determine work procedures of planned project activities from various literatures), 17 (groups were able to process answers from members to solve other group questions), 18 (groups remained consistent with the results of answers without being influenced by other groups), 19 (using natural developers according to the group literature), 20 (natural developers who were found to be different from other groups), 21 (how to make natural developer extracts different from other groups), 22 (the design of the pancake packaging label was different from other groups), 23 (the existence of the pancake making tool used was different from other groups), 24 (the existence of the ingredients The pancake used is different from the other groups), 25 (the appearance of the pancake is different from the other groups) and 26 (the taste of the pancake is different from the other groups. others), so only 25 items were used on the creativity observation sheet.

Creativity has 4 aspects, namely fluency (fluency), flexibility (flexibility), elaboration (detailed), and originality (original). Statement items 1, 2, 3, 4, 5, 6, and 7 are part of the fluency aspect, statement items 8 , $9,10,11,12,13$, and 14 are part of the flexibility aspect, statement items 15, 16 are part of elaboration aspects, and statement items 17, 18, 19, 20, 21, 22, 23, 24, 25 parts of the originality aspect. The items of the instrument can accurately be used to measure the object to be measured with the measurement results accurately reflecting the characteristics of the object. This statement is also in accordance with the results of research by Divayana et al., (2017) that basically, the measurement results of the measurement process are a quantity that can reflect accurately and with certainty about the actual situation or facts of what is to be measured through instrument items.

\section{Conclusion}

The results of the research that have been carried out can be concluded that the ethnoscience-based worksheets that have been developed are feasible to be used as teaching material for processing materials for craft and entrepreneurship subjects. The use of ethnoscience-based worksheets can increase student creativity in processing material. 


\section{References}

Asbanu, Y.W.A., Wijayati, N., dan Kusumo, E. (2019). Identifikasi senyawa kimia ekstrak daun sirsak (Annona muricata L.) dan uji aktivitas antioksidan dengan metode DPPH (2,2-Difenil-1-Pikrilhidrasil). Indonesian Journal of Chemical Science, 8(3), 153-160.

Darmiyanti. (2017). Pengembangan Modul Prakarya dan Kewirausahaan Berorientasi Pembelajaran Kontekstual untuk Siswa SMA. Tesis tidak dipublikasikan. Bandar Lampung: PPs Universitas Lampung.

Depdiknas. (2006). Permendiknas Nomor 22 Tahun 2006 Tentang Standar Isi. Jakarta: Departemen Pendidikan Nasional.

Dewi, I.N., Poedjiastoeti, S., dan Prahani, B.K. (2017). EISII learning model based local wisdom to improve students' problem-solving skills and scientific communication. International Journal of Education and Research, 5(1), 107-118.

Dhanti, W.R., Fauziah, Y., dan Syafi'I, W. (2019). The development of student worksheet with search, solve, create, share (SSCS) model based on ethnoscience and critical thinking at education class x ecology SMA. Jurnal Online Mahasiswa, 6(2), $1-13$.

Divayana, D.G.H., Agung, A.A.G., Sappaile, B.I., Simatupang, W., Sastrawijaya, Y., Sundayana, I.M., dan Sugiharni, G.A.D. (2017). Utilization of open source technology in determining of validity and reliability of evaluation model instruments based on ANEKA values in order to evaluate the quality of computer learning. Journal of Theoretical and Applied Information Technology, 95(20), 55175534.

Fitria, M., dan Wisudawati, A.W. 2018. The development of ethnoscience-based chemical enrichment book as a source literacy source of students. International Journal of Chemistry Education Research, 2(1), 50-57. https://doi.org/ 10.11428/jhej1987.42.189

Khoiri, A., Nulngafan, Sunarno, W., dan Sajidan. (2019). How is students' creative thinking skills? an etnoscience learning implementation. Jurnal Ilmiah Pendidikan Fisika Al-BiRuNi, 8(2), 153-163. https://doi.org/10.24042/jipfalbiruni.v0i0.4559

Khotimah, H., Utami, S.P., dan Mursali, S. (2018). Pengembangan LKS berbasis kearifan lokal untuk peningkatan keterampilan penyelesaian masalah siswa. Jurnal iLmiah Biologi, 6(2), 143-151.

Nisa, A., Sudarmin dan Samini. (2015). Efektivitas penggunaan modul terintegrasi etnosains dalam pembelajaran berbasis masalah untuk meningkatkan literasi sains siswa. Unnes Science
Education Journal, 4(3), 1049-1056. https://doi.org/ 10.15294/ usej.v4i3.8860

Novaliyosi., Tola, B., dan Rahayu, W. (2018). Development of pre-service teacher activity sheets with concrete-representational-abstract (CRA) approach for mathematical logical thinking ability. International Journal of Innovation in Science and Mathematics, 6(4), 121-124.

Okwara, O.K., dan Upu, F.T. (2017). Effects of ethnoscience instructional approach on student achievement and interest in upper basic science and technology in Benue State, Nigeria. International Journal of Scientific Research in Education, 10(1), 69-78.

Pratama, R.A., dan Siregar, A. (2019). Pengembangan lembar kerja peserta didik berbasis scaffolding untuk melatih pemahaman konsep. Indonesia Journal of Science and Mathematics Education, 2(1), 84-97. https://doi.org/10.24042/IJSME.V2I1.3975

Rahayu, W.E., dan Sudarmin. 2015. Pengembangan modul IPA terpadu berbasis etnosains tema energi dalam kehidupan untuk menanamkan jiwa konservasi siswa. Unnes Science Education Journal, 4(2):920-926. 10.15294/usej.v4i2.7943

Septiana, R., Gani, R.A., dan Elizabeth, Y. (2018). Hubungan kreativitas belajar siswa dengan hasil belajar ilmu pengetahuan alam. Prosiding Seminar Nasional PGSD, di Universitas Pakuan pada tanggal 10 Maret 2018 ,ISBN 978-623-90058-2-5, h. 6-10.

Siagian, P., Simanjuntak, E., dan Samosir, K. (2018). Disseminating prototype of mathematics learning tools of secondary senior school (SMA) in improving ability of solving problem on Sumatera Utara Province. International Journal of Innovation in Science and Mathematics, 6(3), 111-117.

Suastra, I.W., dan Yasmini, L.P.B. (2013). Model pembelajaran fisika untuk mengembangkan kreativitas berpikir dan karakter bangsa berbasis kearifan lokal Bali. Jurnal Pendidikan Indonesia, 2(2), 221-235. undiksha.v2i2.2166

Sudarmin, Febu, R., Nuswowati, M., dan Sumarni, W. (2017). Development of ethnoscience approach in the module theme substance additives to improve the cognitive learning outcome and student's entrepreneurship. International Conference on Mathematics, Science and Education, di Semarang pada tanggal 3-4 September 2016, Conf. Series 824 (2017) 012024. https://doi.org/10.1088/17426596/755/1/011001

Sudarmin, Zahro, L., Pujiastuti, R.S.E., Ashyar, R., Zaenuri, Rosita, A. (2019). The development of PBL-based worksheets integrated with green 
chemistry and ethnoscience to improve students' thinking skills. Jurnal Pendidikan IPA Indonesia, 8(4), 492-499. https://doi.org/10.15294/jpii.v8i4.17546

Syamsuhidayat, S., dan Hutapea, J.R. (1991). Inventaris Tanaman Obat Indonesia. Jakarta: Badan Penelitian dan Pengembangan Kesehatan Departemen Kesehatan RI.

Toharudin, U., dan Kurniawan I.S. (2017). Sundanese cultural values of local wisdom: integrated to develop a model of learning biology. International Journal of Sciences: Basic and Applied Research). 32(1), 29-49.

Usman, N., Rahmatan, H., dan Haji, A.G. (2019). Ethnoscience based module development on material substance and its characteristics to improve learning achievement of junior high school students. International Journal of Innovation in Science and Mathematics, 7(3), 148-157.

Wiyanto, Nugroho, S.E., dan Hartono. (2017). The scientific approach learning: how prospective science teachers understand about questioning. Journal of Physics: Conference Series, 824(1), 1-4. https;://doi.org/10.1088/17426596/755/1/011001

Zahary, M. (2017). Pengembangan Lembar Kerja Peserta Didik (WORKSHEETS) Menggunakan Pendidikan Multikultular untuk Meningkatkan Kemampuan Pemahaman Konsep Matematika dan Sikap Sosial Siswa. Tesis tidak dipublikasikan. Bandar Lampung: PPs Universitas Lampung. 